\title{
Exploring Instructional Design in Arabic Education
}

\author{
Donna Hess \\ The University of Arizona
}

\begin{abstract}
This review examines instructional design principles from Behaviorist, Cognitivist, Constructivist, and Contemporary learning inspired models within the landscape of Arabic language education research. Specific characteristics from instructional design models such as ADDIE, Morrison, Ross, and Kemp, ASSURE, and Rapid Prototyping are explored within the context of the Arabic classroom that uses technology integration. It will be shown that there is a need for more studies to emphasize the importance of design within course development to benefit both instructors and learners of Arabic. This synthesis of current research will be helpful to Arabic educators and researchers in determining best collaborative and comprehensive strategies for designing effective Arabic language learning environments to propel the field into the future.
\end{abstract}

Keywords: Arabic education, Instructional design, online, technology

Online language teaching and learning programs have increased in many educational environments throughout the world due to recent interest in online education (Paudel, 2021). Either as a natural outcome of technological innovation, as a result of the worldwide COVID-19 pandemic, or both, there is a plethora of options to explore languages in contexts such as fully online, asynchronous environments and hybrid courses (Levy \& Stockwell, 2006; Paudel, 2021). As such, Arabic teaching and learning has experienced significant growth in the United States and throughout the world. Universities have seen an increase in the number of students studying Arabic, and Arabic language programs in government and in Islamic studies continue to expand (Husseinali, 2006; Nissim, 2004; Rahman, 2014). Globally, there are over 313 million speakers of Arabic, and 25 independent states and territories list Arabic as their native language (World Population Review, 2021). This increase in interest as well as the shift to more online and blended environments shape the future of Arabic education (Ryding, 2013; Weber \& Hamlaoui, 2018). When considering how to organize an online Arabic language environment, the 
technological tools to achieve student success have been found to not be as important as the design and pedagogical practices applied to the instruction (Hamilton, 2013; Moneypenny \& Simon, 2017). Therefore, it is imperative to understand the importance of instructional design of effective language teaching strategies and techniques and how they can be applied to the online Arabic language environment.

Instructional Design is, "a discipline in which practitioners constantly look to the findings of other disciplines (e.g., cognitive psychology, communication) to study and improve methods of developing, delivering, and evaluating instruction and instructional practices." (Brown \& Green, 2020). When designing instructional systems, design represents the broad picture of how instruction will flow throughout the entirety of the course with the overall emphasis on the learner. Effective design understands the needs of the learners and the learning context and considers the perspective of the learner above that of the content (Morrison et al., 2007; Naidu, 2013). Therefore, design features in the Arabic language course (objectives, activities, and assessments) are developed and implemented according to the pre-assessed needs of the learner (Morrison et al., 2007).

Although the process of instructional design is applicable to all courses, online language course design includes additional characteristics that are unique to the learning environment, such as the format and delivery of the content (Vai \& Sosulski, 2016). Authoring systems are programs that allow users to create computer-assisted language learning (CALL) products that appear commercially produced and enhance the look of the course. Additionally, the LMS, as an integrated tool, is used to create and manage the online course and provides a professional-looking application to deliver course content in one "easy-to-use" template (Blake \& Guillen, 2020; Czerkawski et al., 2017; El Mawas et al., 2016; Pacansky-Brock, 2017). Instructional design in online language learning, which includes the authoring systems and LMS, is therefore critical in developing a successful and effective online Arabic language environment.

Instructional design must also be implemented within the framework of effective language teaching strategies. Edward Anthony (1963), an American applied linguist, coined three levels of conceptualization and organization of language teaching which were termed approach, method, and technique. Anthony (1963) stated, "The organizational key is that techniques carry out a method which is consistent with an approach" (p. 63). Using this concept, a language instructor has a set of assumptions and beliefs about language and language learning which are then turned into methods and put into practice according to a theory.

Another way to describe this organization of language teaching is what Ryding (2013) refers to as the teacher language awareness (TLA) that informs, "management of classroom instruction" (p. 3). As an example of these processes, Arabic instructors must be aware of the ideological and philosophical beliefs about the importance of learning spoken and/or written variants of the language and then establish procedures in the classroom to address these factors. This is perhaps the most important issue to consider when preparing to teach Arabic; it will define how to teach it through the design and 
procedures of the classroom. Richards and Rodgers (2014), describe design in language teaching as the, "level in which objectives, syllabus, and content are determined, and in which the roles of teachers, learners, and instructional material are specified" (p. 29). Additionally, technique refers to "the level at which classroom procedures are described" (Richards \& Rodgers, 2014, p. 22). All levels of organization in teaching (approach, method, design, and technique or procedures) affect, and are affected by, the integration of technology in the Arabic classroom.

Technology can capture students' attention, stimulate language exploration, and support second language (L2) learning (Blake \& Guillen, 2020). Therefore, teachers are encouraged to increasingly utilize more digital technologies in the Arabic classroom. These technologies are best utilized within an effective design that supports sound language teaching strategies for student success (Naidu, 2013). Given that Arabic is a global language and continues to grow in online offerings, it is imperative that researchers focus efforts on how instructional design is being integrated into existing online and hybrid programs to improve Arabic language education. Current research into this topic is not represented well in the literature, and there is a real need to understand the current state of design in online, hybrid, and traditional Arabic education. These important topics will be explored by providing a comprehensive look at research into Arabic programs that integrate technology in a variety of instructional settings. First, six prominent instructional design models will be reviewed within the context of educational learning theories. Next, the process to choose relevant studies will be discussed and each will be analyzed based on how instructional design is utilized in Arabic research. Finally, implications for practice and future research will be discussed.

\section{Instructional Design Models in Arabic Education}

Many traditional education learning theories such as Behaviorist, Cognitivist, Constructivist, and Contemporary inform instructional design models (Levy \& Stockwell, 2006; Naidu, 2013; Ryding, 2013).

\section{Behaviorist Models}

Two models that fall within the ideals of behaviorism (Skinner, 1974) are The Dick and Carey (1968) and the ADDIE (1975) models, which are both first generation models in instructional design.

The Dick and Carey (1968) model is goal oriented and procedural in nature and contains nine steps in the design process that culminate in the evaluation of instruction (Dick, 1996; Seel et al., 2017). In applying this design, the language instructor would first identify the skills and knowledge that the learner is expected to acquire, and then through a series of analyses of the learners and language contexts, develop objectives to assess the learner's performance. The final step in the model is to design and conduct a summative evaluation of instruction to assess its effectiveness (Dick \& Carey, 2009; Obizoba, 2015; Seel et al., 2017). 


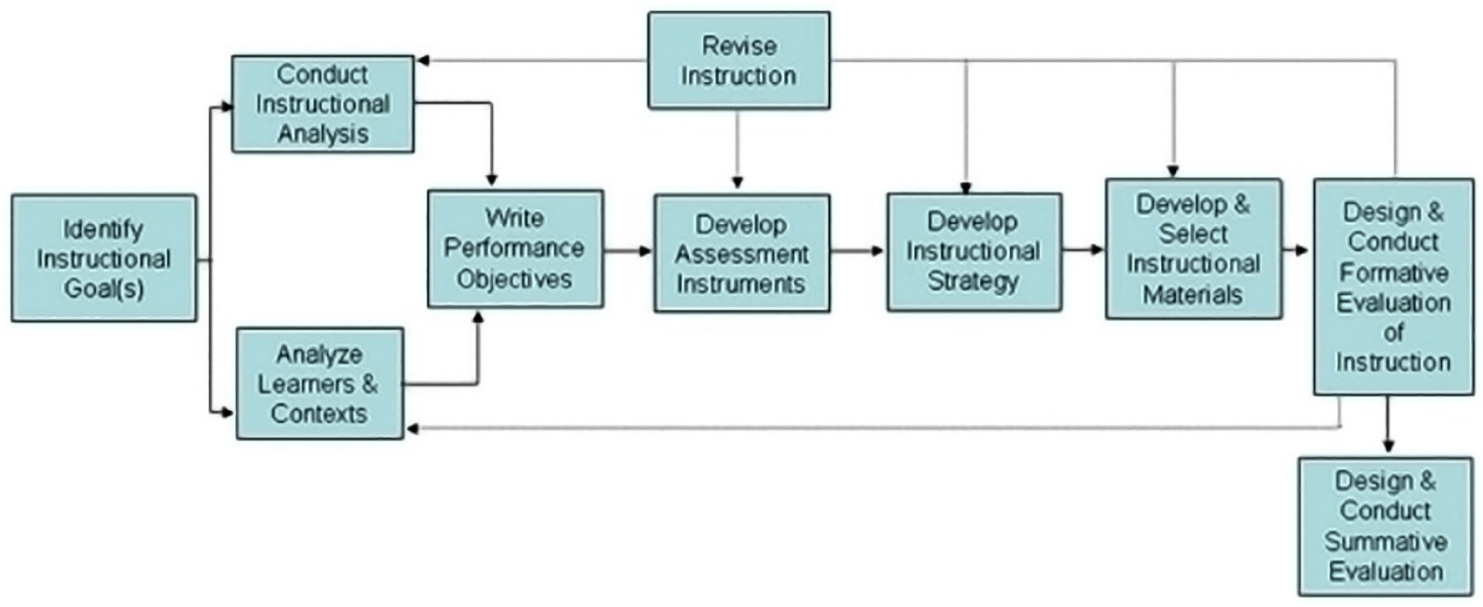

Figure 1. The Dick and Carey, 1968, Model of Instructional Design

The ADDIE model (Analyze, Design, Develop, Implement, and Evaluate) (Russell \& Murphy-Judy, 2020) accounts for infrastructure within the language course, technologies, media, and of course, who the learners are in relation to the targeted language instruction. The language instructor considers, "learning goals, philosophies, approaches, and strategies for realizing the desired learning outcomes" (Russell \& Murphy-Judy, 2020, p. 4). Additionally, the students are actively participating in the instruction and interactions of the course toward communicative competence in the language (Branch, 2009; Russell \& Murphy-Judy, 2020). Engagement strategies within this model encourage social interactions using the target language.

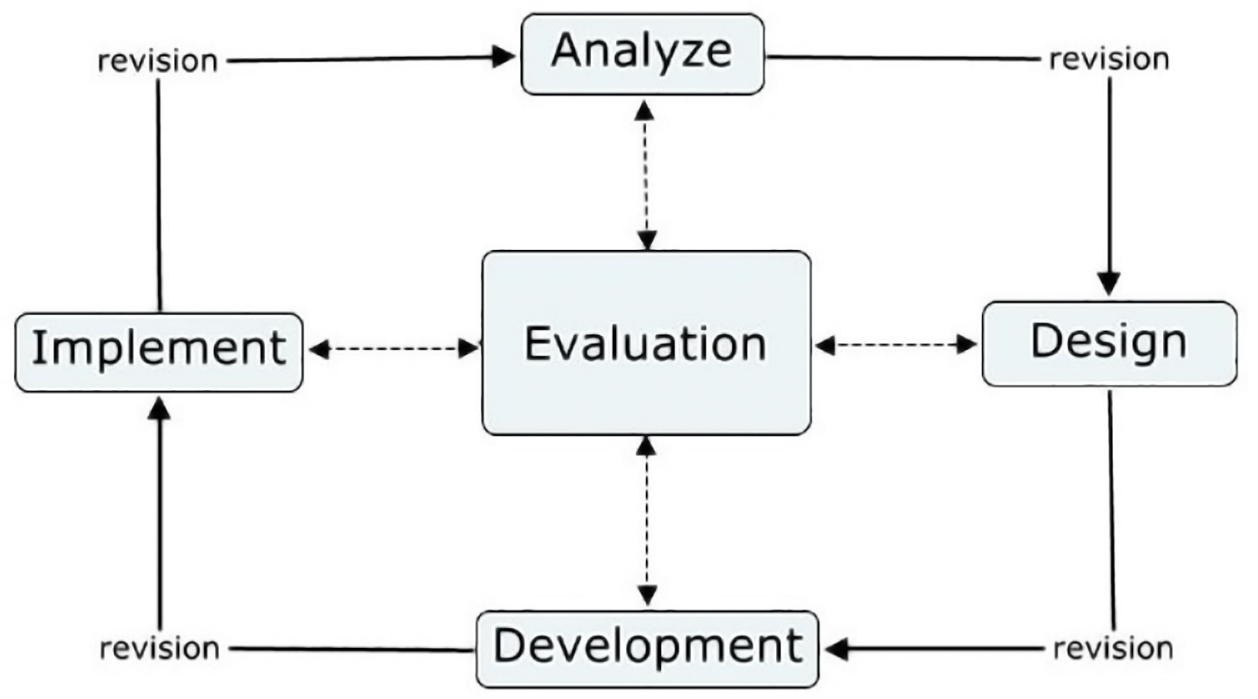

Figure 2. The ADDIE (1975) Model of Instructional Design 


\section{Cognitivist/Constructivist Models}

Cognitive learning theory focuses on how knowledge is acquired, constructed, and represented in the mind of the learner. Constructivism draws on the works of Piaget, Dewey, and Vygotsky (Levy \& Stockwell, 2006; Richards \& Rodgers, 2014) and learners construct meaning internally through an active process of learning according to their own personal reality (Ally, 2008; Richards \& Rodgers, 2014). Two instructional design models that fall under the umbrella of these learning theories are The Morrison, Ross \& Kemp (2007) model, and ASSURE (1996) (Heinich et al., 1996).

The Morrison, Ross, and Kemp (2007) model of instructional design consists of design elements that are integrated within four fundamental design planning components: learners, objectives, methods, and evaluation (Morrison et al., 2007). This model considers the design of the language learning environment, how to motivate the language learner and instructional strategies to enable the learner to master the objectives of the course. This instructional design model is flexible and learner-centered, making it an ideal model on which to evaluate Arabic language courses that are conducted as online, hybrid, or in person courses using integrated technologies (Bajracharya, 2019).

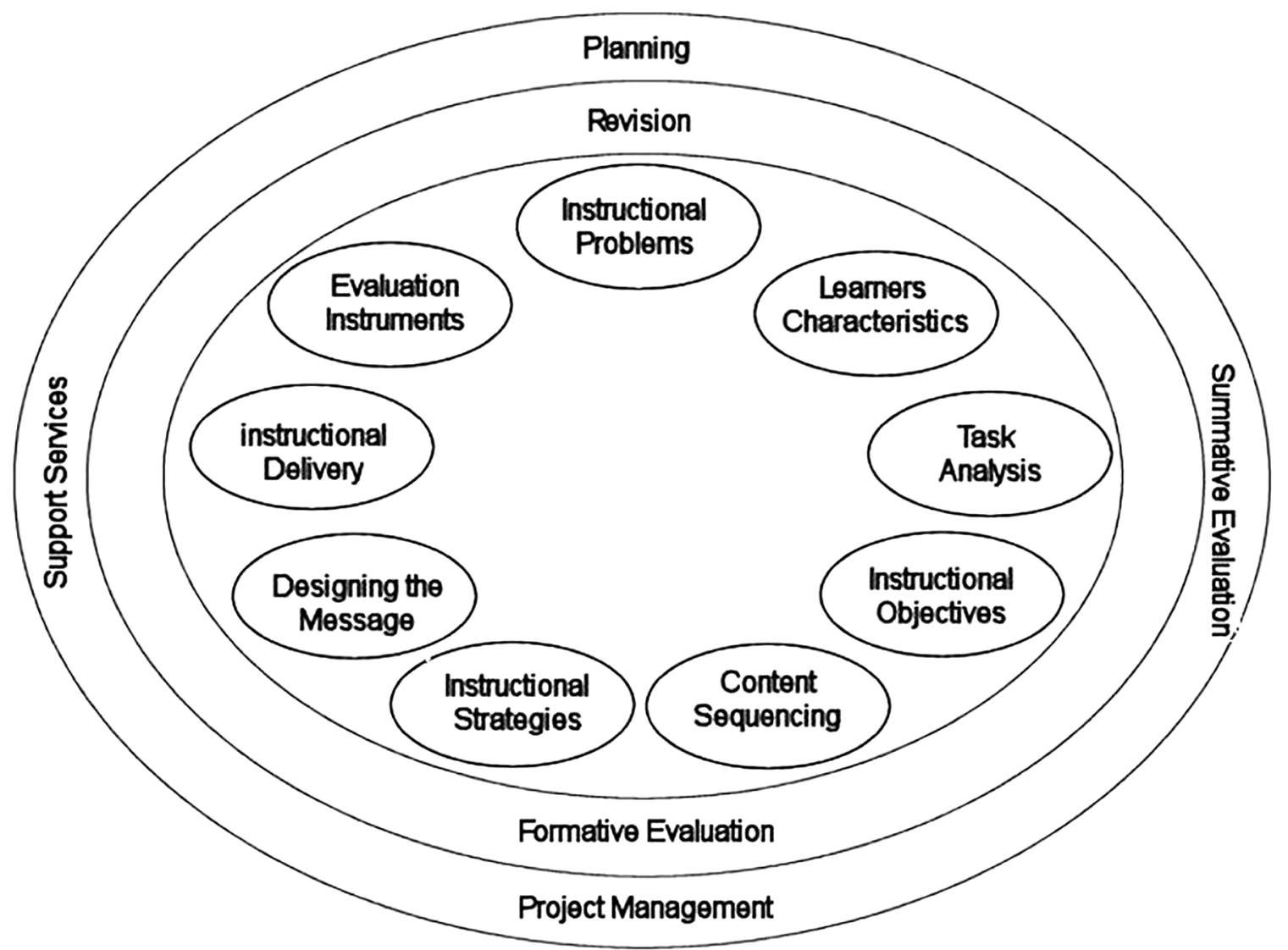

Figure 3. The Morrison, Ross and Kemp (2007) Model of Instructional Design 
A final instructional design model that falls under cognitivist/constructivist learning theories is ASSURE (1996). ASSURE (1996) specifically addresses technology integration in the classroom as it was developed to guide teachers in how to plan and deliver lessons that effectively integrate technology, media, and materials into the language classroom (Kim \& Downey, 2016).

This model consists of a six-step design process:

1. Analyze learners,

2. State standards, and objectives;

3. Select strategies, technology, media, and materials;

4. Utilize technology, media, and material;

5. Require learner participation; and

6. Evaluate and revise (Smaldino et al., 2015).

In this six-step process, the model helps the instructor to, "select, use, and evaluate technology and instructional resources as important parts of the systematic design process (Kim \& Downey, 2016). The Morrison, Ross, and Kemp (2007) model and ASSURE (1996) models represent design approaches that were born out of cognitivist and constructivist education movements and remain popular instructional design models currently used.

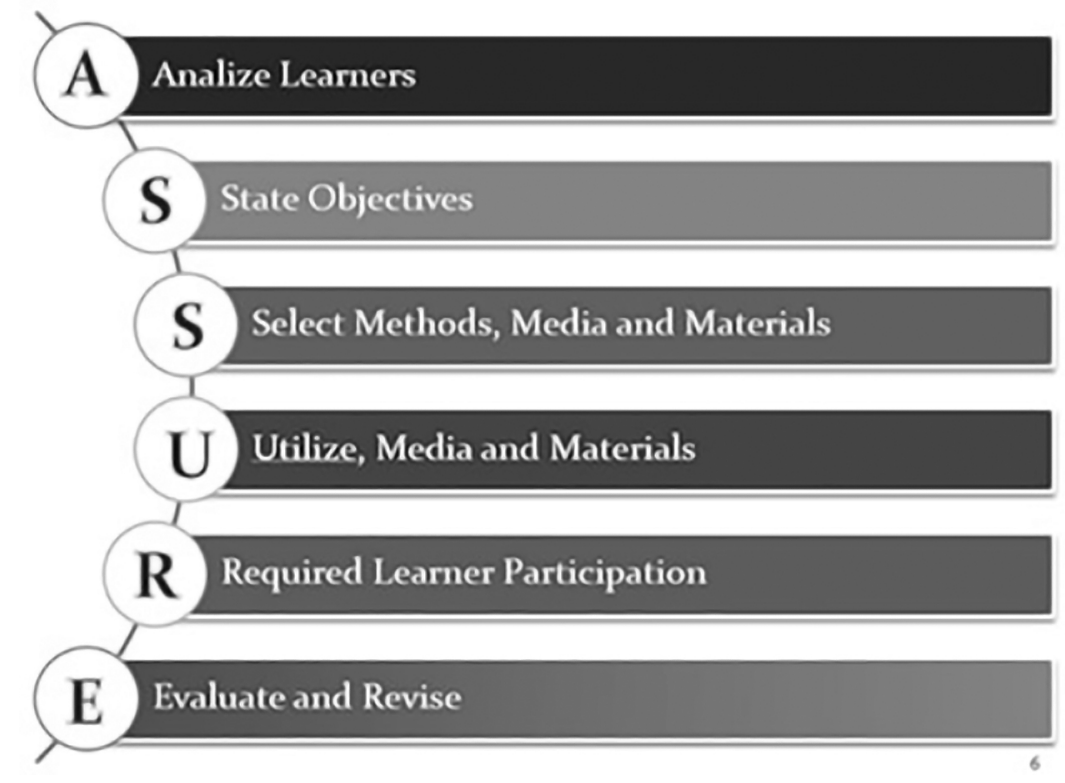

Figure 4. The ASSURE (1996) Model of Instructional Design 


\section{Contemporary Models}

Reflective models emphasize the experience of creation and encourages designers to be cognizant of the current conditions in the design of instruction and to reflect on how it will influence those impacted, such as the students and instructors. Recursive models are those that allow designers to reflect on and address issues or problems many times throughout the design process in a more creative manner (Willis, 1995). Two models that represent these more contemporary ideas toward instructional design are R2D2 and Rapid Prototyping models.

R2D2 encourages the integration of four elements - recursive, reflective, design and development, and disseminate - that serve as focal points during the instructional design process. In language learning, use of blogs, interactive conferencing tools, collaborative writing, and other group learning activities and technologies help to assist in this creative model of learning (Bonk \& Zhang, 2006).

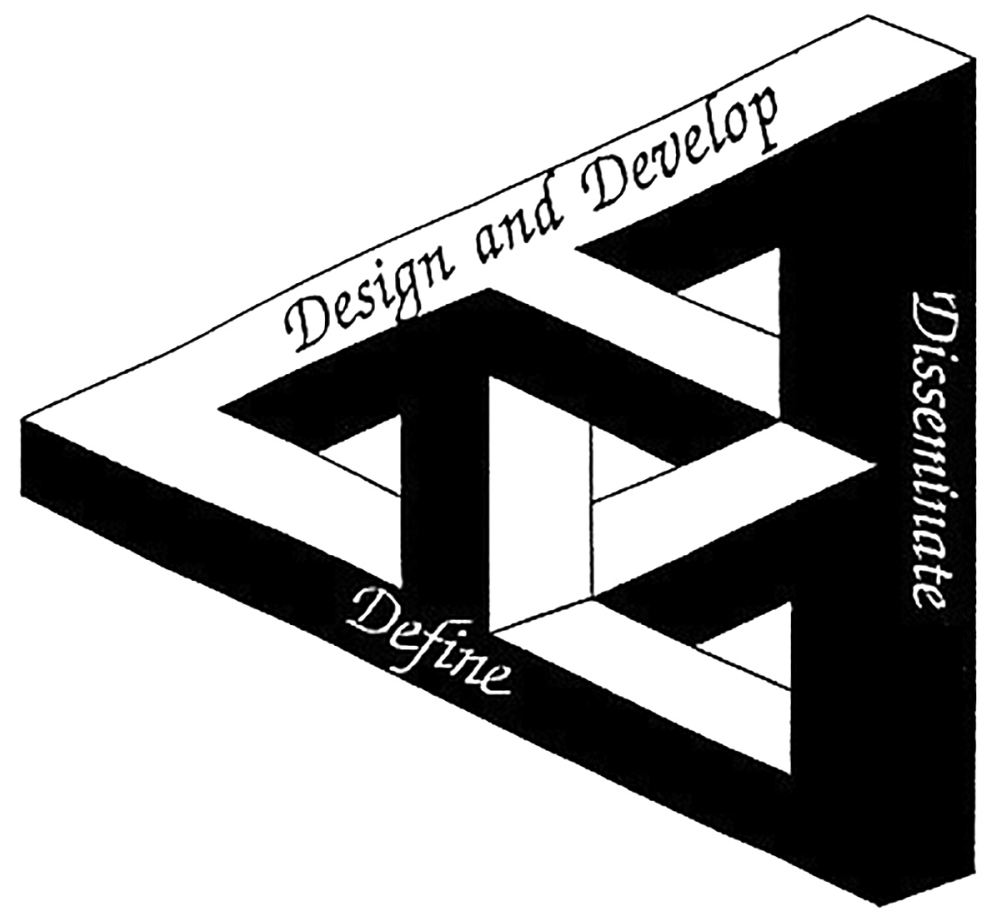

Figure 5. The R2D2 Model of Instructional Design

Rapid Prototyping (1985) is a model that stems from similarities instructional designers share with software designers to create effective material. The model is arranged for parallel processes to be carried out simultaneously. In language learning, this model can be used to test a tutorial software program on willing language students, to design a full system for later use in a larger cohort of language users (Tripp \& Bichelmeyer, 1990). Both R2D2 and Rapid prototyping (1985) represent mod- 
els developed more recently with the advent of computer technology, and are heavily influenced by other fields, especially in computer and other hard sciences.

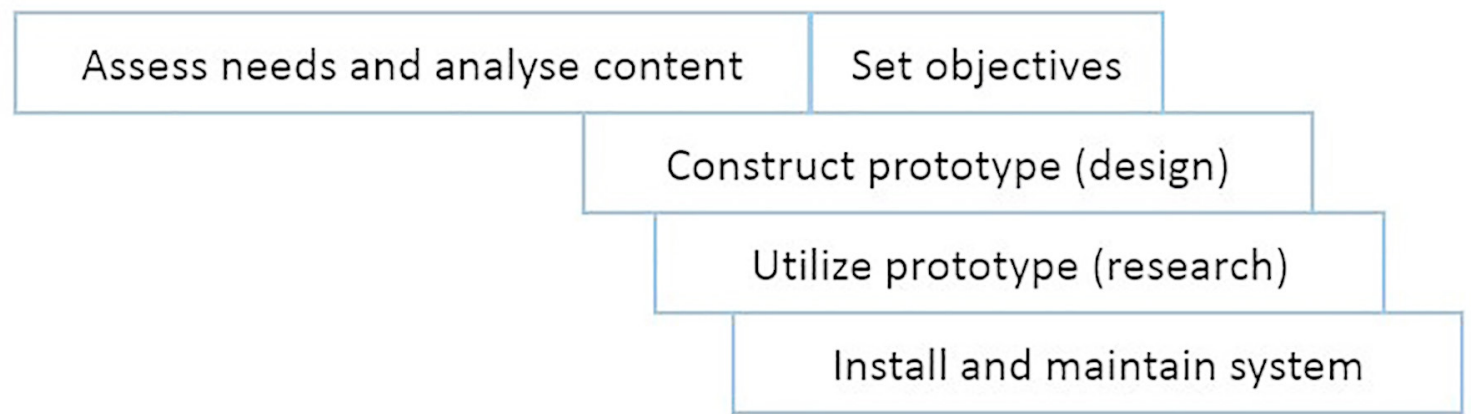

Figure 6. The Rapid Prototyping (1985) Model of Instructional Design

\section{Method of Review}

This review was guided by one central question: What are the principles found across the empirical research on instructional design in Arabic language education within Behaviorism, Cognitivist/Constructivist, and Contemporary learning theories?

\section{Study Inclusion Criteria}

Focusing on in-person, hybrid, and fully online Arabic language learning classes that integrate technology in the administration, instruction, and/or assessment of language content, the research includes hybrid university classes, military language classes, and instructors and students of Arabic in grade school levels K-12. The studies presented in this review offer a wide scope of the Arabic language landscape.

\section{Literature Search Process and Analysis}

The studies for this review were located using three search strategies. First, electronic searches were conducted in the following databases: ERIC, ProQuest, and JSTOR. Keywords used in the initial database and journal searches included general terms (e.g., "online education," "language learning," "language teaching," "e-learning," "virtual learning") as well as more specific terminologies (e.g., "Arabic," "technology," "CALL," "blended learning," "Arabic as a second language," "Arabic as a foreign language," "instructional design in Arabic education").

Second, peer-reviewed journals on language learning, language teaching, and integration of technology in language education were manually reviewed (e.g., Modern Language Journal, Studies in Second Language Acquisition, Language Teaching Research, Language Learning and Technology, Computer Assisted Language Learning, CALICO Journal, Studies in Second Language Learning and Teaching, Language and Education, International Journal of Bilingual Education and Bilingualism, International Journal of Applied Linguistics, Journal of Language Education, L2 Journal, Foreign Language Annals, 
and Journal of Education). Third, reference lists of several collected studies on Arabic education were mined for other compatible studies, especially those that emphasized CALL or technology integration in the Arabic language classroom. Although the literature search was open to all years, the earliest study was published in 1999 and the most recent in 2020.

\section{Findings}

The focus of this review was to explore the landscape of research on instructional design principles in Arabic language education. A total of 25 empirical studies were included in this review with a time span of 1999 to 2020 . A majority of the studies (84\%) were published in the last decade, from 2011 - 2015 (40\%) and 2016 - 2020 (44\%). The research studies on Arabic education were presented equally as qualitative studies (48\%) and quantitative studies (48\%) and only $4 \%$ were presented as mixed methods (Table 1 ).

Most of the studies reviewed (60\%) targeted beginning and intermediate levels of Arabic instruction to adults at university programs. A total of $32 \%$ of the studies were in the United States, 28\% were in Middle East North Africa (MENA), 12\% were in Malaysia, and $12 \%$ were in other online/worldwide locations such as Indonesia and Palestine. Military and government personnel were also represented in $12 \%$ of the studies at the Arabic Basic and Intermediate Course Program at the Defense Language Institute Foreign Language Center (DLIFLC) in Monterey, CA, and Department of Defense language school for Fifth Special Forces Operations Group at Fort Campbell, KY.

Younger learners of Arabic in grade school were also represented in the empirical studies with grades $1-4$ representing $20 \%$ and grades $5-7$ representing $4 \%$ of studies. Some of the studies reviewed (8\%), were in non-specific, worldwide Arabic language settings. One study reviewed Arabic massive open online courses (MOOCs) in the Middle East, one study took place at an Arabic teaching professional workshop, and a third study targeted language learners in a cultural and religious tutoring program available to learners from potentially around the world.

Table 1. Characteristics of Research on Technology Integration in Arabic Education

\begin{tabular}{lccc}
\hline & Characteristics & $\mathbf{n}$ & \% \\
\hline Publication Year & & \\
$1996-2000$ & 2 & 8.0 \\
$2001-2005$ & 2 & 8.0 \\
$2006-2010$ & 0 & 0.0 \\
$2011-2015$ & 10 & 40.0 \\
$2016-2020$ & 11 & 44.0
\end{tabular}


Table 1., continued

Characteristics

\section{Design}

Qualitative

Quantitative

Mixed Methods

\section{Content Area}

Modern Standard Arabic

Not specified

MSA and Dialect

Participants (students and teachers)

University Beginning and Intermediate

Grades 1-4

Defense Language Institute/Military

Not specified

Grades 5-7

Context of Instruction

In person

Online

Hybrid

\section{Source}

Journal Article

Dissertation
16

$20 \quad 80.0$

$3 \quad 12.0$

28.0

13

52.0

$5 \quad 20.0$

$3 \quad 12.0$

$3 \quad 12.0$

$1 \quad 4.0$

8

64.0

32.0

1

4.0

In the following, 25 empirical studies are analyzed according to design in Arabic education within the frameworks of Behaviorist, Cognitivist/Constructivist, and Contemporary learning theories.

\section{Instructional Design Principles from the Behaviorist Models}

The two behaviorist models, Dick and Carey (1968) and ADDIE (1975) have principles which are highly represented in Arabic education specifically related to goals of instruction, outcomes produced as a result of instruction, and consequences of instruction (Kay \& Kibble, 2016). These teacher-centric approaches as they apply to Arabic education refer to the overall goal of instruction and communicative output as either MSA or dialect, In $80 \%$ of the studies, the focus for instruction was on Modern Standard Arabic (MSA) with various country and cultural contexts. Arabic teachers in $24 \%$ of studies functioned as the primary source or models of language learning (Al Busaidi et al., 2016; Al Hirtani, 2020; Al Musawi et al., 2016; Attia, 2011; Arrabtah \& Nusour, 2012; Haley \& Ferro, 2011). In $32 \%$ of studies, communicative competence was the main goal of the 
instruction, as opposed to complete control of the structure of the language. In Arabic teaching, this approach emphasizes using a spoken variety in support of, or in lieu of MSA in speaking activities and classroom interactions. Several studies expressed the importance that teachers placed on students' ability to converse with native speakers (Ahmed, 2015; Harless et al., 1999; Sulaiman, 2015) and thus, the role that integration of technology played in facilitating face-to-face speaking interactions (Fassetta,et al., 2017; Osman, \& Hamzah, 2017) or simulated interactions for speaking practice (Bush \& Brown, 2004; Harless et al. 1999; Omari, 2015). Designing course materials to help students master communicative skills aligns with the Dick and Carey (2009) step, "develop instructional strategy," and the ADDIE (1975) step, "Implement" and is a key pedagogical strategy in CALL. As Omari (2015) stated, "Such instruction not only enhances learning," but it, "also ameliorates students' understanding of the culture of the target language by offering them opportunities to interact with native speakers" (p. 622).

Adding to the authenticity of language learning, Corpora, or "records of language behavior" provided a wealth of legitimacy to the language learning experience in Arabic education studies. This important design feature, developing and implementing quality language software and lessons that includes authentic written and spoken text, is what Bush and Brown, (2004) called, "the representations of the language used" as, "the highest fidelity with respect to the real world in which the language is spoken" ( $p$. 508). Corpora was present in $36 \%$ of studies as part of an emphasis on the importance of learning Arabic language material in the context of culture (Ahmed, 2015; Bush and Brown, 2004; Fassetta et al., 2017; Hammad, 2019; Harless et al., 1999; Holland et al., 1999; Mahmoud et. al., 2013; Omari, 2015; Sulaiman, 2015; Zaki, 2017). Additionally, $28 \%$ of studies highlighted the significance of learning from native or heritage speakers/ original sources (Ahmed, 2015; Fassetta et al., 2017; Hammad, 2019; Harless, et al., 1999; Mosa \& Kakehi, 2015; Omari, 2015; Zaki, 2017). One student in the Ahmed (2015) study appreciated that, "technology provides access to current news; live broadcast and authentic resources to hear new terms/phrases used in 'real life' situations" to emulate in speaking (p. 66). Designing these resources (interactions using technology and language learning software) into the Arabic classroom showed a clear expectation that students show communicative competence in the language and represented clear design steps from the two behaviorist models.

In language studies designed for government professionals and military personnel (Ahmed, 2015; Harless et al., 1999; Holland et al., 1999), competency tests are standard, as assessments in reading, listening, and speaking are performed during and at the conclusion of language courses. Not only is technology used throughout the instruction of the course, all final testing for reading and listening proficiency testing is performed in a laboratory setting with the use of computer terminals and audio-visual devices (Ahmed, 2015; Harless et al., 1999, Holland et al., 1999). This principle of consequences of instruction from behaviorism models Dick and Carey (1968) and ADDIE (1975) were represented in Arabic education studies in additional to goals for instruction and outcomes as a result of instruction. 


\section{Instructional Design Principles from the Cognitivist/Construc- tivist Models}

The cognitivist and constructivist models, Morrison, Ross, and Kemp (2007) and ASSURE (1996), were incorporated in Arabic education studies, specifically related to identifying instructional needs and learner assessments, strategies for student-centric technology integration, and performance assessments. Studies identified the instructional problem related to identifying the needs of the student (Ahmed, 2015; Almansour, 2019; Arrabtah \& Nusour, 2012; Hammad, 2019, needs of the institution (Ahmed, 2015; Al-Busaidi et al., 2016; Al Musawi et al., 2016), and the collective Arabic language learning community (Attia, 2011; Fassetta et al., 2017; Harless, et al., 1999; Haley \& Ferro, 2011). In 20\% of the studies, specific standards needed for language learners to achieve were known prior to designing the language learning materials (Al-Busaidi, 2016; Ahmed, 2015; Arrabtah \& Nusour, 2012; Harless et al., 1999; Holland et al., 1999). Arrabtah and Nusour (2012) specifically mentioned that the purpose of their study was to compare students' achievement in Arabic grammar using a new instructional method integrating technology with the more traditional strategy of teaching Arabic grammar so as to assess its effectiveness on learner achievement (p. 336).

Closely related to the instructional design principle of a need's assessment is being aware of learner characteristics. In $68 \%$ of the studies learner characteristics such as academic level (Ahmed, 205; Al Anshory, 2019; Al-Busaidi, 2016; Al Musawi, 2016), government professional characteristics (Ahmed, 2015; Harless et al., 1999; Holland et al., 1999), culturally diverse learners (Sulaiman, 2015; Hammad, 2019; Omari, 2015), and adult learners (Ahmed, 2015; Al Anshory, 2019; Alhirtani, 2020; Arrabtah \& Nusour, 2012; Attia, 2011; Blake \& Shiri, 2012; Bush \& Brown, 2004; Fassetta et al., 2017; Hammad, 2018; Harless et al., 1999; Holland et al., 1999; Mosa \& Kakehi, 2015; Omari, 2015; Osman \& Hamzah, 2017) were discussed. Knowing learner characteristics was especially important because, "by being sensitive and alert to the characteristics of special groups of learners, a designer can plan programs especially effective for them" (Morrison et al., 2007, p. 61). Attia (2011) touches on this concern as the teacher participants were concerned with using strategies to address exactly what their Arabic students needed to accomplish in their classes (p. 114; 140; 164).

A needs and learner assessment not only identified gaps in performance which helped in establishing objectives and activities, but it also highlighted critical needs to establish a baseline for what all learners should be able to accomplish. Morrison et al. 2007, states that a thorough needs and learner assessment helps to properly apply an intervention (such as technology), to improve student performance (p. 32).

The ASSURE (1996) model specifically addresses the most effective means of integrating technology into the design of learning (Kim \& Downey, 2016). In 36\% of the Arabic studies, technology was strategically placed in the classroom to help students meet specific objectives of the course. Arabic teachers overwhelmingly supported the integra- 
tion of technology in classroom instruction to meet standards (Ahmed, 2015; Al-Busaidi et al., 2016; Alwaely \& Lahiani, 2020; Arrabtah \& Nusour, 2012; Hammad, 2019; Harless, et al., 1999; Omari, 2015; Samy, 2006; Sulaiman, 2015). Technology integration was supported even if the procedures for implementing activities and providing feedback via technological means were not polished (Attia, 2011; Haley \& Ferro, 2011; Holland et al., 1999; Omari, 2015; Zulaini et al., 2020). In Attia's (2011) study of Arabic teachers' cognition and technology use in practice and the work environment, the participants recognized their role in integrating more technology for activities they previously would not have considered suitable in which to integrate it. "One of the positive aspects of this study is that I felt the need to develop, to learn more about technology.... It gave me a positive push forward" (p. 213). As teachers became more aware of technology to assist in meeting objectives, they were more apt to integrate it into their teaching.

The Morrison, Ross and Kemp (2007) and ASSURE (1996) models are specifically learner-centric that emphasize student involvement in the learning process. In $32 \%$ of the studies student-centered approaches represented an emerging approach to teaching with technologies (Almansour, 2019; Blake \& Shiri, 2012; Fassetta et al., 2017; Haley \& Ferro, 2011; Mahmoud et al., 2013; Mosa \& Kakehi, 2015; Osman \& Hamzah, 2017; Sahrir \& Yusri, 2012). Within the Fassetta et al. (2017) study, a teacher (in training) mentioned the online education environment had much to contribute to student-centric learning: "I have always valued the power of technology, but I have always hated doing online teaching-related jobs....but now I see the potential of practicing innovative student-centered pedagogy. I experienced what it means to give up 'control' and power in such a radical way" (p. 144).

Performance Assessments are important for instructional design in order to identify current performance and any potential problems such as lack of skills/knowledge, lack of motivation, administrative factors, and social relations (Morrison et al., 2007). In the Arabic language education studies, a common concern among both student and teachers alike was that there was inadequate training for the technology being used. Researchers reported the need for teacher professional development (Arrabtah \& Nusour, 2012; Attia, 2011; Omari, 2015) as well as more time to implement changes into existing curriculum (Alhirtani, 2020; Arrabtah \& Nusour, 2012; Attia, 2011). Attia (2011) noted that the teachers in the study, "believe that the general orientation in their workplace is in favor of ICT use, but in reality, there is little evidence of careful planning" for technology integration (p. 197). Teachers felt overwhelmed with the amount of time and planning it would take to implement technology changes in their teaching of Arabic (Arrabtah \& Nusour, 2012; Attia, 2011) and students sometimes became frustrated with technology requirements in the Arabic classroom (Ahmed, 2015; Sahrir \& Yusri, 2012). One student in a Arabic game-based study stated that he, "didn't' know how to use it (the dictionary), just appeared but I didn't know (how to use), cannot understand” (Sahrir \& Yusri, 2012, p. 969). 
The studies added that some of the problems faced by learners when using game-based Arabic vocabulary activities were, "related to understanding the new words and meaning, getting used to game's activities and could not read the Arabic instructions on the computer" (p. 970).

Performance assessments in Arabic education studies also listed concerns with infrastructure issues. Consistent challenges were reliable Internet connectivity (Al Anshory \& Salis, 2019; Osman \& Hamzah, 2017; Sahrir \& Yusri, 2012; Zulaini et al., 2020), funding requirements to finance computer equipment (Al-Busaidi et al., 2016; Arrabtah \& Nusour, 2012; Omari, 2015; Osman \& Hamzah, 2017) laboratories (Al-Busaidi et al., 2016; Arrabtah \& Nusour, 2012; Omari, 2015), and language program subscriptions (Omari, 2015; Osman \& Hamzah, 2017). Finally, studies noted that existing software and hardware in many of the Arabic programs were outdated and needed to either be repaired, updated, or replaced (Al-Busaidi et al., 2016; Bush \& Brown, 2004; Omari, 2015) with consistent technology support available to students and teachers (Ahmed, 2015; Attia, 2011). As one teacher in Al-Busaidi et al. (2016) stated, "Arabic language teachers need their own special language labs which are equipped with computer, multimedia facilities, a projection TV and a big screen. Also, school administrators should keep all computer facilities up-graded and maintained" (p. 150).

The existence of instructional needs and learner assessments, strategies for student-centric technology integration, and performance assessments showed that design principles from the Cognitivist and Constructivist models of Morrison, Ross, and Kemp (2007) and ASSURE (1996) were present in much of the Arabic education research.

\section{Instructional Design Principles from Contemporary Models}

Contemporary models of instructional design had few principles represented in Arabic education with the exception of the Rapid Prototyping concept of parallel design for the Construct and Utilize steps (Lantz, 1985). In $40 \%$ of studies, original language learning software (Al-Busaidi, 2016; Bush \& Brown, 2004; Hammad, 2019; Mosa \& Kakehi, 2015), tutorials, (Bush \& Brown, 2004; Harless et al., 1999; Mahmoud et al., 2013), microworlds (Holland et al., 2019) , games (Sahrir \& Yusri, 2012), and other CALL related teaching strategies (Bush \& Brown, 2004; Blake \& Shiri, 2012; Shaalan, 2005) were being tested on small numbers of cohorts for potential use with larger numbers of language learners in future iterations of classes. In several studies, it was stated that if the program objective results were positive, then additional testing would be conducted on larger groups for permanent implementation (Al-Busaidi, 2016; Blake \& Shiri, 2012; Mahmoud et al., 2013; Mosa \& Kakehi, 2015; Sahrir \& Yusri, 2012). As Bush and Brown (2004) state, the field of technology integration in the Arabic classroom is, "poised to make great strides" (p. 487). New designs in language software and other original applications will help to create or discover new problems to explore before implementation in the Arabic classroom. 
Contemporary theories on education and the models R2D2 and Rapid Prototyping (1985) were not has notable in Arabic education studies in a variety of instructional settings. Although technology is playing a larger role in Arabic education, traditional teaching methods and technology integration are still facing challenges in implementation.

\section{Discussion}

The goal of this review was to identify instructional design principles within Behaviorism, Cognitivist/Constructivist, and Contemporary learning theories across the empirical research on Arabic language education that has some form of technology integration within it. Using models that are representative of the main goals of these learning theories, this review highlighted many design principles within Arabic education. Identifying these design principles serve as a current state of practice in Arabic education and possibilities for the future of instructional design in the field.

Arabic education research that included some form of technology integration revealed that practitioners had an existing knowledge of challenges and strategies for including design principles in the educational setting. There were strategic choices made in goals of the instruction, specifically related to communicative competence and student verbal production expectations. The research revealed that despite the expected outcome for verbal communication, $80 \%$ of courses were conducted primarily in MSA, thus creating a potential conflict for the design of instruction. Arabic language instructors, by default, must design carefully how MSA and spoken dialects are integrated into the curriculum of the class and then how production will be assessed. Studies showed that instructors created unique solutions to integrate technology to expose students to spoken varieties from cultural sources, native and heritage speakers, and primary news and radio sources from MENA. There must be proper alignment between MSA and spoken dialects as Ryding (2013) states, "Formal classroom instruction in Arabic does not often take into account the realm of natural, every day, spoken Arabic" which can hinder, "access to serious study and acquisition of 'performance fluency' as well as normal discourse skills" (p. 3). This review affirms that the existing studies sought to address this concern through deliberate design of instruction and objectives for attaining balance between MSA and a spoken variety in the Arabic classroom.

Despite the inclusion of technology within the Arabic classroom in a variety of instructional contexts, this review disclosed many challenges this poses to design, principally, how to strategically integrate it so students achieve standards. Studies showed that many participants felt technology was a part of the class, but not helping to achieve a particular goal, therefore, it served little purpose. Participants in some studies mentioned being frustrated using the tool if there was no instructional value toward an objective. It is known that technology can help mediate interactions in the online or hybrid classroom as well as target language development through original software, tutorials, games, and microworld experiences. Integrated technology in the Arabic classroom must help learners achieve specific goals as developed by the instructor. The future of Arabic education and technology use within it shows tendencies of moving toward more online and hybrid 
offerings, therefore, there must be clear design strategies to effect positive change. As El Essawi (2018) contends, technology, "has created a new world where learning not only takes new forms but also happens in new spaces" (p. 385). Using these new technologies and learning spaces (online) must contribute to language achievement or they will simply be a hinderance to learners.

Finally, the studies revealed a lack of comprehensive design strategies informed from learning theories on how technology is integrated in Arabic education. One or two principles from models aligned with Behaviorist, Cognitivist, Constructivist, and Contemporary learning strategies were identified in studies in this review. However, comprehensive use of a specific model, informed by a particular learning theory, did not exist in a single study. Some principles related to identifying learner needs and assessments (as discussed in Cognitivist and Constructivist models of Morrison, Ross and Kemp (2007) and ASSURE (1996)) were located within studies that followed a more behaviorist theoretical base for instruction. This is to be expected, as all models share the goal of learners achieving something after instruction and learning theories are not all inclusive. Best practices of foreign language pedagogy and best practices for online/hybrid/CALL teaching were not present in the research and thus lacked a comprehensive design plan for instruction.

\section{Implications for Practice}

This review highlighted several challenges to implementing instructional design within Arabic education. As more online and hybrid learning opportunities are available, instructors either have to be trained in basic design principles or have access to an instructional design team to assist in creating effective language learning curriculum. There is a clear need for Arabic practitioners to have basic design training and knowledge of appropriate models that coincide with a preferred learning theory. This implies full support of administrators and institutions in recognizing the value of technology integration in the Arabic classroom and the resources in trained personnel to achieve a successful program. Additionally, there must be adequate training for personnel currently in the teaching profession who seek to integrate more CALL strategies in the Arabic classroom. Properly designed technology that is strategically integrated will achieve greater success among learners and will create paths for more Arabic language learning opportunities in the future.

As Arabic language programs continue to expand in technology use, practitioners must also be mindful in how to best achieve communicative competence. This is a complicated topic as MSA and spoken varieties do not necessarily reinforce each other in vocabulary or fluency. "Different programs will take different approaches to this issue, making decisions based on institutional goals, curricular objectives, and student needs" (Ryding, 2013, p. 177). A major question will be if learners can achieve functional proficiency in a dialect from classroom instruction that is mainly in MSA. "To make informed decisions, faculty and administrators need to know the options open to them, the needs and goals of their students, the availability of materials, and what kind of spoken Arabic 
is authentic in which situations" (Ryding, 2013, p. 177). Instructional design will play a major role in helping to establish best practices for learners to meet these goals, especially as it relates to a chosen model according to a learning theory.

\section{Implications for Research}

This review examined instructional design principles from Behaviorist, Cognitivist, Constructivist and Contemporary learning inspired models. Based on these studies, there are three recommendations for future research: Research into design principles in Arabic education must increase, instructional design must be comprehensive and student-centered, and collaboration with other specialties is essential to transform the Arabic teaching practice.

As online and hybrid Arabic classes are becoming more normalized and available, and technology is being integrated into classes, more research is needed to determine the current state of instructional design principles present in Arabic education. There is a need for more studies to integrate design into course development, assessing the success or failures of the design features, pedagogical challenges, evaluation of student achievement, and recommendations for best practices. Rigorous research in qualitative, quantitative, and mixed-methods approaches will present the Arabic education field with more effective teaching strategies using instructional design principles that will benefit both instructors and learners of Arabic.

This review also identified an awareness of the importance of identifying learner needs and learner characteristics prior to instruction. However, a more comprehensive approach to design will emphasize Arabic learner's unique needs in achieving language skills in MSA and dialect. An effective design allows instructors to set goals and strategies for meeting national and international standards as well as integrating technology in strategic positions within the course to accomplish these goals. "Learners come from diverse cultures with diverse learning needs, motivations, and contexts" (Alosh, 2019). A comprehensive design strategy that is learner focused allows for specific proficiency strategies to be implemented in instruction, thus contributing to student success in the language. Arabic instructors already face unique challenges in appropriating time and materials to MSA or dialect, and a comprehensive design strategy ensures attention is focused on the needs of the learner.

Finally, there needs to be increased research on collaborative efforts between fields such as instructional design, foreign language, technology, graphic art, and others to transform current thoughts on designing, developing, implementing, and evaluating the Arabic language classroom. Arabic education is transforming to include more integrated technology, CALL principles and pedagogy, and asynchronous academic instructional settings. Challenges in designing and developing effective instruction can be alleviated by creating collaborative efforts with other specialties in education and business to pro- 
duce the best possible product for the learner. Learners' needs, motivations for learning Arabic, preferences for study, and access to the language should be considered so that researchers can create these collaborations to best design Arabic classrooms to meet these specific language challenges.

By exploring instructional design in Arabic education, the areas that need further development and research become apparent. Recent research reveals that some design principles such as defining instructional goals, needs assessments, learner characteristics, performance assessments and parallel design are present in Arabic education studies. Future research should consider more collaborative and comprehensive strategies for designing effective Arabic language learning environments to propel the field into the future. 


\section{References}

Ahmed, E. (2015). Modern standard Arabic learners' views about the effect of portable technology on L2 learning proficiency in listening and reading at the Defense Language Institute Foreign Language Center. ProQuest Dissertations Publishing.

Al Anshory, A. \& Salis, R. (2019). The use of information technology-based Arabic learning media in the Arabic Language Center (PKPBA) Universities Islam Negeri Maulana Malik Ibrahim Malang. Tarling: Journal of Language Education, 3(1), 4157.

Al-Busaidi, F., Al Hashmi, A., Al Musawi, A., \& Kazem, A. (2016). Teachers' perceptions of the effectiveness of using Arabic language teaching software in Omani basic education. International Journal of Education and Development using Information and Communication Technology 12(2), 139-157.

Alhirtani, N. (2020). The use of modern teaching methods in teaching Arabic language at higher education phase from the point view of Arabic language professors - A case of a Premier University. International Education Studies, 13(1), 32-41.

Almansour, S. (2019). A statistical analysis of engagement in Arabic language MOOCs (Doctoral dissertation). Retrieved from ERIC.

Al Musawi, A., Al Hashmi, A., Kazem, A., Al Busaidi, F. \& Al Khaifi, S. (2016). Perceptions of Arabic language teachers toward their use of technology at the Omani basic education schools. Education and Information Technologies 21, 5-18.

Alosh, M. (2019). Unleashing the power of the learner. In M. Lo (Ed.), The Arabic classroom: Context, text, and learners (pp. 131-138). London: Routledge.

Alwaely, S. \& Lahiani, H. (2020). Assessing argumentative writing skills in online environments among Arabic language teachers of grades 5 to 7 in UAE schools. International Journal of Emerging Technologies in Learning 15(18), 202-217.

Anthony, E. M. (1963). Approach, method, and technique. English Language Teaching, 17: $63-7$.

Arabic speaking countries (2021). World population review 2021. Retrieved January, 21, 2021, from https://worldpopulationreview.com/country-rankings/arabicspeaking-countries

Arrabtah, A. \& Nusour, T. (2012). Using technology for teaching Arabic language grammar. Journal of International Education Research, 8(4), 335-342.

Attia, M. (2011). Teacher cognition and the use of technology in teaching Arabic to speakers of other languages. Dissertation. 
Blake, R. \& Guillen, G. (2020). Brave New Digital Classroom: Technology and Foreign Language Learning. Washington, D.C.: Georgetown University Press.

Blake, R. \& Shiri, S. (2012). Online Arabic language learning: What happens after? L2 Journal, 4, 230-246.

Bonk, C. \& Zhang, K. (2006). Introducing the R2D2 model: Online learning for the diverse learners of this world. Distance Education, 27(2), 249-264.

Branch, R. (2009). Instructional design: The ADDIE approach. Athens, GA: Springer.

Brown, A. \& Green, T. (2020). The essentials of instructional design: Connecting fundamental principles with process and practice. Routledge: New York.

Bush, M. \& Brown, J. (2004). Teaching Arabic with technology at BYU: learning from the past to bridge to the future. CALICO Journal, 21(3), 497-522.

Czerkawski, B. \& Gonzales, D. (2014). Major trends, issues, and challenges with learning management systems. In T. Yuzer \& G. Eby (Eds.), Handbook of Research on Emerging Priorities and Trends in Distance Education. IGI Global.

Dick, W. (1996). The Dick and Carey model: Will it survive the decade? Educational Technology Research and Development, 44(3), 55-63.

Dick, W. \& Carey, L.M. (2009). The systematic design of instruction. Boston: Allyn and Bacon.

El Essawi, R. (2018). Importance of a collaborative tech-based learning model for teacher education. In K. Wahba, L. England, \& Z. Taha (Eds.), Handbook for Arabic Language Teaching Professionals in the $21^{\text {st }}$ Century, Volume II (pp. 385397). Routledge: New York and London.

El Mawas, N. Oubahssi, L. \& Laforcade, P. (2016). Identification and Formalization of LMS Instructional Design Languages: Moodle Case Study. In Zvacek, S., Restivo, M. Uhomoibhi, J. \& Helfert. M. (Eds.), Computer Supported Education (pp. 21-36). Switzerland: Springer International Publishing.

Fassetta, G., Imperiale, M., Frimberger, K., Attia, M., \& Al-Masri, N. (2017). Online teacher training in a context of forced immobility: The case of Gaza, Palestine. European Education, 49, 133-150.

Haley, M. \& Ferro, M. (2011). Understanding the perceptions of Arabic and Chinese teachers toward transitioning into U.S. schools. Foreign Language Annals, 44(2), 289-307).

Hamilton, M. (2013). Autonomy and foreign language learning in a virtual learning environment. ProQuest Ebook Central. 
Hammad, M. (2019). The impact of a web-based leveled reading program on Arabic language learners' reading experiences. Foreign Language Annals, 52, 413-432.

Harless, W. G., Zier, M. A., \& Duncan, R. C. (1999). Virtual dialogues with native speakers: The evaluation of an interactive multimedia method. CALICO Journal, 16, 313-337.

Heinich, R., Molenda, M., Russel, J. D., \& Smaldino, S. E. (1996). Instructional media and technologies for learning ( $5^{\text {th }}$ ed.). Hillsdale, NJ: Prentice-Hall.

Holland, V.M., Kaplan, J.D., \& Sabol, M.A. (1999). Preliminary tests of language learning in a speech-interactive graphics microworld. CALICO Journal, 16, 339-359.

Kay, D. \& Kibble, J. (2016). Learning theories 101: Application to everyday teaching and scholarship. Advanced Physical Education, 40(17-25), 17- 25.

Kim, D. \& Downey, S. (2016). Examining the use of the ASSURE model by k-12 teachers. Computers in schools: Interdisciplinary Journal of Practice, Theory, and Applied Research, 33(3), 153-168.

Lantz, K. (1985). The prototyping methodology. Englewood Cliffs, NJ: Prentice Hall.

Levy, M. \& Stockwell, G. (2006). CALL Dimensions: Options and Issues in Computer Assisted Language Learning. New York: Routledge.

Mahmoud, A., Sahrir, M., \& Osman, A. (2013). Integration of an Interactive Program in Learning Arabic Language for Non-Native Speakers via Virtual Tutor. Journal of Language Studies, 13(3), 117-131.

Moneypenny, D. \& Simon, J. (2017). Best practices in online second language teaching: Theoretical consideration in course design and implementation. In R. Alexander (Ed.). (2017). Best practices in online teaching and learning across academic disciplines (pp. 107-120). ProQuest Ebook.

Morrison, G., Ross, S., \& Kemp, J. (2007). Designing Effective Instruction. New Baskerville: John Wiley \& Sons, Inc.

Mosa, A. \& Kakehi, K. (2015). A way of supporting non-Arabic speakers in identifying Arabic letters and reading Arabic script in our new E-Learning system. EAl Endorsed Transactions, 2(6), 1-8.

Naidu, S. (2013). Instructional design models for optimal learning. In Moore, M. (Ed.), Handbook of distance education (pp. 268-281). New York: Routledge.

Nissim, C. (2004). Teaching Islam and Arabic over the Internet. CALICO Journal, 21(3), 561- 564. 
Obizoba, C. (2015). Instructional design models - frameworks for innovative teaching and learning methodologies. The Business and Management Review, 6(5), 2131.

Omari, S. (2015). The effect of computer-assisted language learning on improving Arabic as a foreign language (AFL) in higher education in the United States. Procedia - Social and Behavioral Sciences 192, 621-628.

Osman, N., \& Hamzah, M. (2017). Student readiness in learning Arabic language based on blended learning. International Journal of Applied Linguistics \& English Literature, 6(5), 83-89.

Pacansky-Brock, M. (2017). Best practices for teaching with emerging technologies. New York: Routledge.

Paudel, P. (2021). Online education: Benefits, challenges, and strategies during and after COVID-19 in higher education. International Journal on Studies in Education (IJonSE), 3(2), 70-85.

Rahman, A. (2014). The status of Arabic in the United States of America post 9/11 and the impact on foreign language teaching programs. Advances in Language and Literacy Studies, 5(3), 70-81.

Richards, J. \& Rodgers, T. (2014). Approaches and methods in language teaching. Cambridge, UK: University Printing House.

Russell, V. \& Murphy-Judy, K. (2020). Teaching language online: A guide for designing, developing, and delivering online, blended, and flipped language courses. ProQuest Ebook Central.

Ryding, K. (2013). Teaching and learning Arabic as a foreign language: A guide for teachers. Washington, D.C.: Georgetown University Press.

Sahrir, M. \& Yusri, G. (2012). Online vocabulary games for teaching and learning Arabic. Gema Online Journal of Language Studies 12(3), 961-977.

Samy, W. (2006). Instructional Media and Learning Arabic. In K. Wahba, L. England, \& Z. Taha (Eds.), Handbook for Arabic Language Teaching Professionals in the 21st Century, (p. 263-273). Lawrence Erlbaum Associates, Inc.

Seel, N., Lehmann, T., Blumschein, P. \& Podoldkiy, O. (2017). Instructional design for learning: Theoretical foundations. Rotterdam: Sense Publishers.

Smaldino, S., Lowther, D., Russell, J., \& Mims, C. (2015). Teachers discovering computers: Integrating technology in a connected world ( $7^{\text {th }}$ ed.). Boston, MA: Cengage Learning. 
Shaalan, K. (2005). An intelligent Computer Assisted Language Learning system for Arabic learners. Computer Assisted Language Learning, 18(1-2), 81-109.

Skinner, B. F. (1974). About behaviorism. New York: Knopf.

Sulaiman, K. (2015). The effects of information and communication technologies (ICT) on the teachings/learning of Arabic and Islamic studies. International Journal of Islamic Studies 2(1), 1-26.

Tripp, S. \& Bichelmeyer, B. (1990). Rapid prototyping: An alternative instructional design strategy. Educational Technology Research and Development, 38(1), 3144.

Vai, M. \& Sosulski, K. (2016). Essentials of online course design: A standards-based guide. New York: Routledge.

Weber, A. \& Hamlaoui, S. (2018). E-learning in the Middle East and North Africa (MENA) Region. Germany: Springer.

Wiggins, G. \& McTighe, J. (2005). Understanding by design. Alexandria, VA: ASCD.

Willis, J. (1995). A Recursive, reflective instructional design model based on constructivist- interpretivist theory. Educational Technology, 35(6), 5-23.

Zaki, M. (2017). Corpus-based teaching in the Arabic classroom: Theoretical and practical perspectives. International Journal of Applied Linguistics, 27(2), 514541.

Zulaini, N., Mufidah, N., Kholis, N., \& M. Amrulloh (2020). Learning Arabic for elementary schools during the COVID-19 outbreak. Journal of Education, 3(1), 39-55. 